\title{
Perkembangan dan Masa Depan Bahasa Arab
}

\author{
Zaenal Abidin \\ zet46id@uin-alauddin.ac.id \\ Universitas Islam NegeriAlauddin Makassar \\ Andi Satrianingsih \\ Andi.satrianingsih@gmail.com \\ Universitas Muhammadiyah Makassar
}

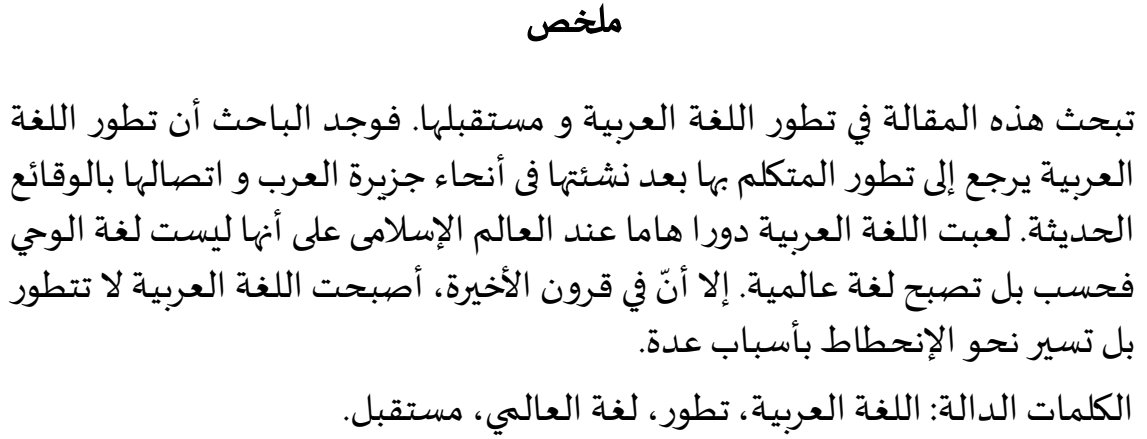

Abstrak

Tulisan ini membahas perkembangan dan masa depan bahasa Arab. Uraian ini menunjukkan bahwa bahasa Arab berkembang sesuai perkembangan penuturnya baik di dalam maupun di luar kalangan dunia Arab dengan menjadi bahasa komunikasi internasional. Bahasa Arab memiliki arti penting karena ia bukan saja bahasa wahyu, tetapi juga sudah menjadi bahasa internasional. Hanya saja dewasa ini, bahasa Arab mengalami stagnasi bahkan cenderung menunjukkan degradasi yang kelihatannya mengkhawatirkan masa depan bahasa Arab. Hal itu disebabkan beragam faktor.

Kata kunci: Perkembangan; bahasa Arab; masa depa; bahasa internasional,

\section{A. Pendahuluan}

Eksistensi bahasa Arab sebagai salah satu bahasa tertua di dunia yang hingga kini masih digunakan menjadi perhatian berbagai kalangan, khususnya para ahli bahasa dan ahli sejarah. Ada kemungkinan bahasa Arab menjadi bahasa pertama bagi manusia pertama sehingga akan menarik perhatian bagaimana perjalanan bahasa ini melewati kurun waktu yang sangat panjang hingga masa kini.

Bahasa Arab dalam perjalanannya di tanah Arab menjadi alat komunikasi wahyu yang kemudian seakan menjadi bahasa resmi agama Islam. Hal itu dapat 
dilihat dalam semua ayat al-Quran dan nukilan hadis-hadis nabi Muhammad saw, yang keduanya adalah sumber utama ajaran Islam. Kenyataan ini menggiring munculnya opini bahwa bahasa Arab merupakan bahasa kaum Muslimin.

Bahasa Arab adalah bahasa yang digunakan oleh orang-orang Arab dalam menyampaikan buah pikiran dan maksud mereka. ${ }^{1}$ Bahasa Arab sebagai salah satu bahasa mayor di dunia memiliki setumpuk keistimewaan dari ciri khas tersendiri yang membedakan dengan bahasa yang lainnya. ${ }^{2}$ Di antara keistimewaan bahasa ini adalah di samping sebagai bahasa sastra yang paling kaya dari segi lafaz dan makna di seluruh dunia, ia juga meruppakan bahasa yang paling mampu mengekspresiskan keindahan bahasa. ${ }^{3}$

Sebagaimana bahasa-bahasa lain memiliki asal-usul sejarah dan perkembangan. Bahasa Arab mula-mula berasal, tumbuh, dan berkembang di Negaranegara kawasan timur tengah, lebih dari itu Bahasa Arab menyebar di dunia internasional hingga diterima dan dinyatakan sebagai salah satu bahasa resmi dunia internasional.

Bahasa Arab dalam keyakinan umat Islam adalah bahasa penghuni surga, sementara surga itu sendiri adalah tempat asal Adam, nenek moyang manusia. Persepsi yang muncul adalah bahwa bahasa Arab telah dipergunakan oleh Adam dan keturunannya di awal kehidupan mereka. Penelitian dengan teori berbeda menunjukkan bahwa asal usul bahasa Arab dihubungkan kepada Sam anak Nabi Nuh yang diutus setelah nabi Adab dengan selisih waktu berabad-abad. Meskipun demikian, jika dihitung dari masa saat ini, bahasa Arab telah berkembang selama ribuan tahun dan masih bertahan hingga zaman modern.

Sejarah perkembangan bahasa Arab berawal pada periode Jahiliyah ketika muncul nilai-nilai standarisasi bahasa Arab fusha pada kegiatan-kegiatan yang telah menjadi tradisi masyarakat Mekah seperti festival syair Arab yang diadakan di pasar Ukaz, Mijannah, Dzulmajaz, dan Khaibar. ${ }^{4}$ Perkembangan selanjutnya berjalan seiring perkembang Islam di dunia Arab hingga luar tanah Arab.

Perkembangan lebih lanjut menunjukkan bahwa pengaruh bahasa Arab tampak semakin luas dalam pergaulan dunia internasional, sehingga sejak tahun 1973 bahasa ini diakui secara resmi sebagai bahasa yang sah untuk dipergunakan di

${ }^{1}$ Al-Syaikh Mushtafa al- Ghulâyainiy, Jami' aj-Durâs al-A rabiyah, jilid 1, (Beirut; alMaktabah al-Ashniyah, 1973), h. 7.

${ }^{2}$ Bahasa Arab dituturkan lebih dari 200 juta ummat manusia yang tersebar kurang lebih di 20 negara, lihat Azhar Arsyad, Bahasa Arab dan Metode Pengajarannya, Beberapa Pokok Pikiran. (Fak. Tarbiyah IAIN Alauddin Ujung Pandang, 1997), h. 1-2.

${ }^{3}$ Muhammad al-Gazali, Turāsunā al-fikra fỉ mizān al-syari ‘ wa al-'aqli diterjemahkan Halid alKaf dan Muljono Domopolii dengan judul Syariat dan Akal dalam Perspektif Tradisi Pemikiran Islam (Cet. I; Jakarta: Lentera, 2001), h. 230.

${ }^{4}$ Haniah, Bahasa Dasar: Bahasa Arab Komunikasi (Cet. I; Gowa: Pustaka Al-Maidah, 2017), h. 5 . 
lingkungan Perserikatan Bangsa-Bangsa. ${ }^{5}$ Bahasa Arab juga dianggap bahasa umat Islam, disebabkan dengan adanya al-Qur'an dan hadis Nabi yang berfungsi sebagai dua sumber pokok ajaran Islam ditulis dalam bahasa Arab. ${ }^{6}$ Ditambah dengan penjelasan kedua sumber utama itu yang tertulis dalam jutaan buku yang berbahasa Arab.

Menyadari pentingnya posisi bahasa Arab dalam kehidupan orang Islam, idealnya bahasa Arab dapat dipahami dan dimanfaatkan dalam pendalaman dan pengamalan ajaran Islam yang bermuara kepada terwujudnya kemaslahatan hidup umat manusia. Faktanya, bahasa Arab menjadi bahasa Asing di tengah kaum muslimin.

Artikel ini mengamati perkembangan bahasa Arab dan menganalisa masa depan bahasa ini guna memberikan pemahaman dan menumbunkan girah atau semangat dalam memanfaatkan bahasa yang sudah menjadi bahasa resmi internasioanal ini.

\section{B. Perkembangan Bahasa Arab}

Banyak sejarawan menyatakan bahwa bahasa Arab adalah bahasa nabi Adam as. Sebuah așar juga meyebutkan bahwa bahasa Arab adalah bahasa penghuni surga, jadi bahasa Arablah yang melahirkan bahasa-bahasa dunia. Bahasa anak cucu nabi Nuh as, seperti Sami, Hami, dan Yafit bersumber dari bahasa Arab. ${ }^{8}$ Pandangan ini juga disebut dengan teori tauqifi yang merupakan pendapat klasik dengan mendasarkannya pada interpretasi QS. Al-Baqarah/2: 31 berikut;

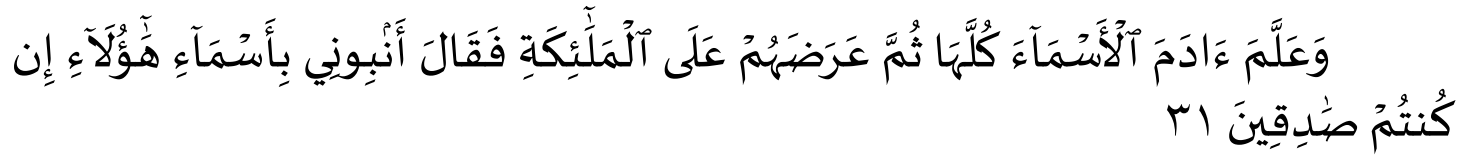

Terjemahnya:

Dan Dia mengajarkan kepada Adam nama-nama (benda-benda) seluruhnya, kemudian mengemukakannya kepada para Malaikat lalu berfirman: "Sebutkanlah kepada-Ku nama benda-benda itu jika kamu mamang benar orang-orang yang benar!

${ }^{5}$ Chatibul Umam, Aspek-aspek Fundamental Dalam Bahasa Arab (Cet. 1; Bandung: PT alMa'arif, 1980), h.15.

${ }^{6}$ Lihat misalnya, QS. Yusuf 12:2, QS. Al-Zumar 39:28 dan ayat lainnya. Ayat-ayat tersebut hanya berbicara tentang Alquran yang diturunkan dalam bahasa Arab. Sedangkan hadis Nabi tidak dijelaskan secara tersurat bahwa hadis itu berbahasa Arab, namun sejarah membuktikan bahwa hadis Nabi yang dikumpulkan oleh para pengumpul hadis, ditulis dengan bahasa Arab sebab Nabi mengucapkannya dengan bahasa Arab.

${ }^{7}$ Aṣar adalah riwayat atau hadis yang sandarannya mencakup apa yang disandarkan kepada Nabi saw, sahabat, dan tabi'in (orang-orang beriman pada rasulullah yang sempat bertemu dengan). Lihat Abd al-Mannan al-Rasikh, Mu'jam Istilāhät al-Hadis al-Nabawiyy diterj. oleh Asmuni, Kamus Istilah-istilah Hadis (Cet. I; Jakarta: PT Darul Falah, 2006), h. 25.

${ }^{8}$ Ali Ali Subhi, "Nazhariyyah al-Jalal: Mukjizat Bahasa al-Qur'an Sepanjang Masa” dalam wawancara oleh PSQ, Jurnal Studi al-Qur'an, Vol II, No 2, Tahun 2007, h. 485. 
Ayat tersebut menunjukkan bahwa nama-nama benda (الأسماء) dan berbagai hal atau sifat di dunia ini telah diajarkan oleh Allah swt kepada Adam dalam bahasa Arab, bahkan pengikut pendapat ini lebih tegas menyatakan bahwa huruf Arab telah dikuasai oleh Adam tanpa belajar. ${ }^{9}$

Pandangan ini nampaknya berbeda dengan ahli sejarah dan ahli Bahasa yang lain, bagi para mu'arrikh dan linguist, bahasa Arab berasal dari satu ras manusia dan rumpun bahasa yang mempunyai peran besar dalam sejarah peradaban kuno yakni bangsa Semit. Kemudian keturunan mereka berpindah tempat meninggalkan tanah airnya dan menetap di lembah sungai Tigris dan Euphrat membentuk rumpun bahasa dan bangsa baru, ${ }^{10}$ seperti Babilonia, Assyiria, Ibrani, Armia, Tunisia dan lain-lain. ${ }^{11}$ Pandangan ini mengidentifikasi bahasa Arab mendapatkan pengaruh alam yang melingkupi para penuturnya dari masa ke masa.

Bahasa Arab dan bahasa-bahasa semit yang serumpun dengannya itu muncul atau lahir dari rumpun yang sama bahkan pada daerah atau tempat yang sama pula, ketika orang-orang semit melakukan perpindahan dari tempat yang satu ke tempat yang lain, maka dengan proses itulah yang menyebabkan percampuran bahasa mereka mulai terjadi, dan proses seperti itu terus berlanjut sampai bahasa yang dari satu rumpun tersebut menjadi bahasa yang bercabang-cabang dikarunakan percampuran antara kabilah yang satu dengan kabilah yang lain baik melalui pernikahan, komunikasi sosial maupun perdagangan. ${ }^{12}$

Bangsa Semit berikut bahasanya dinisbahkan dari putra Nabi Nuh yang bernama Sam ibn Nuh. Garis keturunan Sam inilah yang melahirkan berbagai bangsa dan bahasa, di antaranya bangsa 'Akkadiyyah, Kan'an, Ethopiah, Arab dan sebagainya. ${ }^{13}$ Namun seiring dengan perjalanan umat manusia dari sekian rumpun bahasa Semit, yang tersisa sampai sekarang hanyalah bahasa Arab, bahasa yang telah memberi pengaruh yang cukup besar dalam sejarah peradaban umat manusia, terutama di saat memasuki abad VI masehi.

Menurut para ahli, bahwa bahasa-bahasa di dunia yang jumlahnya diperkirakan hampir 3000 bahasa, paling baik dikelompokkan dengan teori yang berdasarkan hubungan kekerabatan yaitu rumpun bahasa Indo-Eropa, Semit-Hemit

${ }^{9}$ Lihat Haniah, Bahasa Dasar: Bahasa Arab Komunikasi (Cet. I; Gowa: Pustaka Al-Maidah, 2017), h. 3 .

${ }^{10}$ K. Ali. “A Study of Islamic History”, diterjemahkan oleh Ghufran A. Mas'adi dengan judul Sejarah Islam dari Awal Hingga Runtuhnya Dinasti Usmani, Tarkh Pra Moderen, ed I (Cet. I; Jakarta: Raja Grafindo Persada, 1997), h. 1.

${ }^{11}$ Philip K. Hitti, "The Arab Short History", diterjemahkan oleh Ushuluddin Hutagalung dan O.D.P. Sihombing dengan judul Dunia Arab (Cet. III; Bandung: Sumur Bndung, t.th), h. 7.

${ }^{12}$ Ahmad husen al-Zubaidy, tārikh al-Adab al-Arabìy, Cet. XXV, t, tp.

${ }^{13}$ Chatibul Umam et.el. Pedoman Pengajaran Bahasa Arab Pada Perguruan Tinggi Agama IAIN (Jakarta Proyek Pengembangan Sistem Pendidikan Agama RI, 1975), h. 47, lihat juga Bambang Yudi Cahyono, Kristal-Kristal Ilmu Bahasa (Cet. I; Surabaya: Airlangga University Press, 1995), h. 379. 
dan Turania. ${ }^{14}$

Bahasa-bahasa yang termasuk ke dalam rumpun bahasa Indo-Eropa adalah bahasa India, bahasa Iran, bahasa Yunani, bahasa Prancis, Spanyol, Portugis, Italia Rumania, bahasa Inggris, Belanda, Jerman, Denmark, Armania, Albania dan lainlain. Sedang bahasa-bahasa Semit dapat dibagi menjadi dua bahagian, yaitu bahasa Semit Utara, yang terdiri dari bahasa-bahasa Akkadiyah, bahasa Babilonia, bahasa Kan'an dan bahasa-bahasa Aramiah. Sedang bahasa Semit selatan terdiri bahasa mesir (Mesir kuno dan koptik), bahasa-bahasa Barbar yang dipergunakan penduduk asli Afrika Utara, seperti Tunisia, Aljasair, Maroko, Sahara dan sekitarnya serta bahasa Kusyitik, yaitu bahasa penduduk asli bagian timur Afrika seperti bahasa Somalia, Galla, Bedja, Dankali, Agaw, Afar, Sidama dan lain-lain. Adapun rumpun bahasa Turania meliputi bahasa-bahasa Tunisia yang terdiri dari bahasa Turki, Mongolia dan Manmair, bahasa Jepang, bahasa Cina, bahasa Korea, Kaukasia, bahasa Sudan, bahasa Melayu Polinesia (termasuk bahasa Indonesia) ${ }^{15}$

Jika sejarah kemunculan Bahasa didasarkan pada teori tauqifi di atas, dipahami bahwa berbagai macam bahasa yang telah disebutkan di atas sebenarnya berasal dari satu bahasa, yaitu bahasa Arab. Hal itu sama dengan pemahaman bahwa bangsa-bangsa yang ada hingga dewasa ini berasal dari satu keturunan, yaitu nabi Adam. Hanya saja, perpisahan antara satu dengan yang lainnya dan membentuk satu bangsa. Perpisahan antara satu komunitas dengan yang lainnya dengan beragam keadaan alam yang ditempatinya mengakibatkan pembentukan bahasa pergaulan tersendiri yang sudah tidak persis sama dengan bahasa induknya, bahkan dalam proses masa yang cukup panjang semua bahsa turunan seperti terpisah jauh dengan induknya.

Dalam sejarah panjang manusia dengan bahasanya, penamaan bahasa yang bersumber dari bahasa Semit muncul dengan kemunculan bangsa-bangsa yang berasal dari keturunan bangsa Semit itu sendiri, maka muncullah bahasa-bahasa 'Akkadiyah (Abad XX SM) yaitu bahasa yang dipergunakan oleh bangsa Asyuriah dan Babilonia, Bahasa-bahasa Aramiyah (Abad IX SM) dan Abbariyah (sebelum abad XX SM) Finikiyah (Abad XII SM). ${ }^{16}$ Begitu pula muncul bahasa-bahasa Arab, bahasa Yaman Kuno dan bahasa Habsyi. Bahasa Arab lahir dari sebuah rumpun bahasa yang bernama Semit, sebelum datangnya agama Kristen, para peneliti tidak dapat menemukan apapun karena tidak ada bukti dokumen tertulis berupa teks-teks. Kelangkaan teks-teks Arab itu karena meluasnya buta huruf ('ummiyyah) dikalangan bangsa Arab sebelum Islam dating, namun tidak berarti sebelum datangnya agama Kristen bahasa Arab belum ada. Tidak pula berarti bahwa bahasa Arab lebih mudah dibanding dengan bahasa 'Ibrāni dan bahasa-bahasa Semit lain. Bahasa Arab

\footnotetext{
${ }^{14}$ Mulyanto Sumardi et.el, Pedoman Pengajaran Bahasa Arab Pada Perguruan Tinggi Agama Islam IAIN (Jakarta: Proyek Pengembangan Sistem Pendidikan Agama, Departemen Agama RI, 1975), h. 29. Islam, h. 29.

${ }^{15}$ Mulyanto Sumardi et.el, Pedoman Pengajaran Bahasa Arab Pada Perguruan Tinggi Agama

${ }^{16}$ Lihat Ali Abd. Wahid Wafiy, Ilmu al-Lugah (Cet. V; Miṣra: Lajnah al-Bayān al-'Arabiy, 1962), h. 93.
} 
mewarisi dan memelihara unsur-unsur bahasa bahasa Semit asal, berbeda dengan bahasa 'Ibrāni sangat banyak mengalami pembaruan dan itu semakin menjauh dari persamaan dengan bahasa Semit asal. ${ }^{17}$

Bahasa Arab sama halnya dengan bahasa-bahasa Yaman Kuno, bahasa-bahasa Habsy Semit adalah berasal dari satu induk yang sama yakni bahasa bangsa Semit yang berdiam disebelah selatan, tepatnya diwilayah Irak, dengan demikian hubungan bahasa Arab dengan bahasa Semit sangat kuat. Lain halnya dengan bangsa Semit yang ada di utara sangat berbeda dengan bahasa Arab dari berbagai aspek, seperti asal-usul kata, Așwāt dan qawa'id-nya. Sedangkan bahasa-bahasa Yaman Kuno dan bahasa-bahasa habsy-Semit sangat kuat dan lebih dekat dengan bahasa Semit selatan dibanding dengan bahasa Arab.

Menurut Ali Abd al-Wahid Wafiy, informasi yang sempat terekam dalam sejarah dan sampai kepada kita tentang bahsa Arab adalah temuan dari prasasti tentang Arab Baidah yang diperkirakan hidup pada abad I sebelum masehi, sedangkan Arab Baqiyah, informasi yang ditemukan nanti setelah abad V masehi. Sehingga periodisasi pert umbuhan bahasa Arab sangat sulit untuk dilacak. ${ }^{18}$

Bahasa Arab secara tertulis masih sangat sedikit jika dibanding dengan bahasa yang lain, sehingga periodisasi bahasa Arab dan kesusasteraannya hanya terbatas pada zaman jahiliah, masa munculnya Islam yang dibawa oleh Nabi Muhammad Saw, masa Bani Umayyah, Bani Abbasiyah, kemunduran dan periode moderen, ${ }^{19}$ dan yang diperpegangi oleh para ahli, tentang perkembangan bahasa Arab pada masa pra Islam (Jahiliyah) adalah nukilan puisi-puisi yang dikembangkan pada zaman tersebut yang dipindahkan dari generasi ke generasi. ${ }^{20}$

Sejarah panjang bahasa Arab melahirakn klasifikasi menjadi dua bagian utama, yaitu:

\section{Bahasa Arab Baidah.}

Bahasa Arab Baidah atau incrips adalah bahasa Arab prasasti, yang biasa juga disebut dengan istilah Arabiyah al-Nuqusy, karena informasi tentang bahasa ini hanya diperoleh melalui tulisan pada prasasti atau lempengan batu. Bahasa Arab Baidah yang berdiam disebelah utara Hijaz atau negeri yang berdekatan Aramiah, dialek bahasa yang dipergunakan dapat dibagi menjadi tiga bagian yaitu: pertama, dialek Lihyaniyah yang dinisbahkan dari nama kabilah atau suku Lihyan yang tinggal dibagian utara daerah Hijaz beberapa abad sebelum masehi. Para ahli berdeda pendapat tentang asal mula suku itu dan tanggal prasasti-prasastinya pun tidak diketahui secara pasti. Hanya diperkirakan prasasti tertua setelah abad ke II atau satu sebelum masehi, dan yang termuda sekitar abad ke VI masehi. Kedua, lahjah Samudiyah yang disandarkan kepada suku Samad sebenarnya yang dikisahkan

${ }^{17}$ Mulyanto Sumardi et.el, Pedoman Pengajaran..., h. 31.

${ }^{18}$ Ali Abd. Wahid Wafiy, Ilmu al-Lugah.. h. 93

${ }^{19}$ Karl Broklaman, Tarikh al-Adab al-Arabiy, jilid I (Cet. IV; al-Qahirah Dar al-Ma'arif, t.th), h. 30-38.

${ }^{20}$ Lihat Muhammad Suyuti Suhaib, Kajian Puisi Arab Pra Islam (Cet. I; Jakarta: Al-Qushwa, 1990), h. 1-2. 
didalam al-Qur' an secara ringkas dalam perjanjian lama, baik Yunani maupun Roma, dan mahsyur di dalam sejarah jahiliyyah. Suku ini diperkirakan mendiami wilayah antara Hijaz dan Nejed dekat Damaskus. Prasasti dalam bahasa Samud kira-kira abad ke III dan empat masehi. Ketiga, lahjah safawiyah, prasastinya didapati di daerah Shafa', walaupun ada juga yang terdapat didaerah lain di Harah yang terletak antara bukit dan gunung Daruz. Penulisannya diperkirakan antara abad ke III dan VI masehi. Orientalis Jerman, Enno Litman memperlihatkan bahwa rumus hurufhurufnya mendekati huruf Samad, huruf-huruf tersebut kadang-kadang dibaca dari kiri ke kanan atau sebaliknya. ${ }^{21}$

Ketiga dialek di atas berbeda dengan bahas fushah, namun dekat dengan bahasa bahasa Sam. Bahasa Arab Baidah juga ada kemiripan dengan bahasa Aramiyah, semua yang masuk dalam kategori baidah ini telah lenyap oleh dominasi Arab Baqiyah.

\section{Bahasa Arab Baqiyah}

Bahasa Arab Baqiyah adalah bahasa yang masih dipakai oleh bangsa Arab dalam kesusasteraan, tulisan dan karangan. Bahasa ini tumbuh di negeri Hijaz dan Nejed, kemudian tersebar keseluruhan daerah daerah yang pernah memakai bahasa Semit dan Chamit, dari situlah timbul dialek-dialek yang dipergunakan pada masa kini dinegeri-negeri Hijaz, Nejed, Yaman dan daerah-daerah disekitarnya seperti Emirat Arab, Palestina, Yordania, Syiriah, Libanon, Irak, Kuwaid, Mesir, Sudan, Libia, Al-Jazair, Maroko, dan Malta. ${ }^{22}$

Bahasa Arab yang dipergunakan oleh orang-orang Arab sekarang atau yang terdapat dalam al-Qur'an dan hadis Nabi mulanya hanya tumbuh dan berkembang di wilayah Nejed dan Hijaz, namun selanjutnya menyebar ke berbagai daerah, seperti yang telah disebutkan, itu karena adanya Islam yang memberikan pengaruh yang sangat luas terutama setelah diadakan perluasan wilayah kekuasaan. Bahasa Arab Baqiyah dipakai dalam pergaulan sehari-hari, berdagang, bermasyarakat dan dalam pemerintahan. Bahasa Arab ini bisa bertahan dan tidak lenyap seperti saudarasaudaranya-baca: yang serumpun- adalah tidak lepas dari pengaruh dan peran Islam saat itu. Dimana ajaran utama Islam, al-Qur'an menggunakan bahasa Arab Baqiyah. Dengan sendirinya kaum muslimin waktu itu berusaha mengetahui bahasa Arab, bagi yang bukan penutur bahasa Arab Baqiyah yang selanjutnya bahasa Arab menjadi warna dalam pergaulan mereka sehari-hari. Sehingga bahasa-bahasa sebelumnya yang juga diapakai tidak lagi dipergunakan, disamping faktor agama juga faktor politik, otomatis bahasa lainnya akan mati dengan sendirinya karena tidak ada lagi pemakainya. Dalam teori bahasa diakatakan bahwa suatu bahasa bisa hidup jika dihidupkan oleh penuturnya dan sebaliknya ia akan mati saat ditinggalkan oleh penut urnya (tidak dipergunakan lagi sebagai bahasa Komunikasi) ${ }^{23}$

\footnotetext{
${ }^{21}$ Ali Abd. Wahid Wafiy, Ilmu al-Lugah... h. 96-97.

${ }^{22}$ Ali Abd. Wahid Wafiy, Ilmu al-Lugah... h. 103.

${ }^{23}$ Lihat Mahmud Kamil al-Naqah, Ta'lim al-Lugah al' Arabiyah li al-natioqin bi Lugat Ukhra Ushuluhu Mudaakhiluhu, Turuqu Tadrisihi (Makkah al-Mukarramah: Jami'ah Umm al-Qura, 1985), h. 13.
} 
Para pengguna bahasa Arab di seputar jazirah Arab mempunyai dialek yang bermacam-macam diantaranya dialek Quraiys, Huzail, Saqil, hawasin, Kinanah, Taman dan Yaman. ${ }^{24}$ Dialek-dialek ini terus dipergunakan hingga datang Islam bahkan masing-masing suku menggunakan dialek mereka disaat membaca al-Qur'an hingga akhirnya Khalifah Usman bin Affan menyatukan bacaan umat dalam satu lahjah yakni lahjah Quraiys, penyatuan bacaan umat pada waktu itu dengan lahjah Quraiys karena kota Makkah, dimana dialek Quraiys yang dipakai mempunyai letak geografis yang cukup strategis dibanding daerah lainnya, begitu juga Makkah menjadi kota religius dimana Nabi Muhammad SAW. dilahirkan dan tempat untuk umat Islam melaksanakan ibadah haji, dan tentu saja pertemuan antara dialek pun terjadi, namun dialek (lahjah) Quraiys tetap jadi pedoman.

Al-Qur'an sebagai bahasa standar diterima dan dicintai oleh masyarakat awam karena selain mempunyai makna yang dalam, juga susunannya sangat indah dan bagus, hal ini menjadi aset terjalinnya antara bahasa Arab dengan Islam yang selanjutnya dijadikan sebagai bahasa agama dan budaya Islam.

Bahasa Arab Baqiyah adalah bahasa yang digunakan dalam bahasa tulisan, dan bahasa sastra yang sampai kepada zaman sekarang melalui syair Jahiliyah, alQur'an dan al-Sunnah al-Nabawiyah, yang selanjutnya disebut dengan bahasa Arab fushah. Bahasa fushah tersebut bukanlah semata-mata hanya dialek Quraisy, tetapi merupakan perpaduan dari berbagai dialek bahasa Arab. ${ }^{25}$

Dalam buku Fusul fi Fiqh al-Lughah, Ramdan Tawwab menyebutkan bahwa, nama dialek bahasa Arab sebanyak $19 .{ }^{26}$ Kabilah-kabilah Arab yang memiliki bahasa yang fasih ada tiga macam, yaitu Tamim, Ta'i, dan Huzail. Mereka inilah yang terkenal kefasihannya dalam berbahasa, dan bahasa mereka menjadi bahasa standar, yaitu bahasa yang digunakan dalam berinteraksi sehari-hari, bahasa yang digunakan dalam menulis syair, dan bahasa pengantar dalam interaksi perdagangan. ${ }^{27}$ Bahasa arab fushah terkadang juga dinisbahkan kepada dialek dominan dari seluruh dialek yang ada, karena adanya empat faktor yaitu; ekonomi, politik, sosial dan agama. ${ }^{28}$

Keberhasilan umat Islam menduduki wilayah yang sebelumnya berada di bawah kekuasaan nonmuslim, terutama pada abad pertama hijrah periode Umar, telah membawa dampak yang cukup signifikan bagi peradaban Islam. Penaklukan tersebut telah melahirkan gerakan perubahan yang cukup luas mengenai pola perdagangan internasional, perniagaan warga perkotaan, pertanian, kemiliteran, dan pengaturan sistem pemerintahan. Di sisi lain,

${ }^{24}$ Manna' al-Qattan, Mabahis Fi 'Ulum al-Qur'an (Cet. II; t.tp, Masyurat al-Asr al-Hadis, t.th), h. 158 .

${ }^{25}$ Lihat Muhammad Ahmad Abu al-Faraj, Muqaddimah Li Dirasah Fiqh al-Lughah (Beirut: Dar al-Nahdah al-Arabiyah, t.th), h. 91.

${ }^{26}$ Lihat Ramadan Abdul Tawwab, Fusul fi Fiqh al-Lughah (Cet. II; al-Qahirah: Maktabah alHaniji, 1980), h. 120-152.

${ }^{27}$ Lihat Shubhi Shalih, Dirasat fi Fiqhi al-Arabiyah (Cet. II; Beirut: Mansyurat al-Maktabah al-Ahalliyah, 1962 M/1382 H), h. 58.

${ }^{28}$ Lihat Shubhi Shalih, Dirasat fi Fiqhi al-Arabiyah..., h. 50-59. 
dengan semakin bertambahnya komunitas Islam yang berasal dari bangsa Persia dan bangsa-bangsa yang berada di bawah kekuasaan Romawi sebelumnya maka juga menimbulkan persoalan baru bagi dunia Arab Islam yaitu terjadinya distorsi dalam penggunan bahasa fusha oleh mereka sebagai bangsa "pendatang" terhadap mereka yang terbiasa dengan menggunakan bahasa Arab secara fasih.

Pada masa pemerintahan Umar (13-23 H) daerah kekuasaan Islam semakin meluas maka bercampurlah antara pendatang (orang Arab) dengan penduduk asli, namun pendatang masih terisolir. Namun pengisolasian ini menumbuhkan persatuan diantara sesama pendatang yang berkelanjutan dengan persaingan dalam pergolakan ilmu bahasa, dan bahasa Arab sebagai bahasa pemenang sudah barang tentu mempunyai kedudukan yang mulia dan terhormat.

Pada masa pemerintahan Bani Umayyah, pendatang mulai berasimilasi dengan penduduk asli di seluruh lapisan masyarakat mulai dari pemerintahan sampai kepada budak. Dengan hasil asimilasi ini menghasilkan bahasa baru yang merupakan perpaduan dari bahasa Arab dengan bahasa setempat. Walaupun bahasa baru ini muncul, namun bahasa Arab masih tetap dalam kelas arsitokrat (kelas mewah).

Pada masa Umayyah ini, ketinggian martabat sosial seseorang ditentukan oleh kemampuan mereka dalam penguasaan bahasa Arab, kesalahan kecil dalam berbahasa dianggap sebagai kesalahan besar/fatal bagi orang-orang tua mereka, maka wajar jika setiap orang menginginkan setiap putra-putrinya menguasai bahasa Arab dengan mengirim belajar bahasa pada bangsa Badui. Namun, pada masa pemerintahan bani Abbasiyah, para pembesar tidak mengirim lagi putra-putri mereka untuk belajar lansung ke-orang-orang Badui, tapi hanya belajar bahasa Arab di istana, karena sebuah pemikiran agar anak-anak mereka bisa menikmati kemewahan kerajaan dan bisa berbahasa Arab dengan baik dan benar.

Pada akhir pemerintahan Bani Umayyah, mereka melakukan pemurnian bahasa Arab yang selanjutnya dilanjutkan pada masa Abbasiyah baik orang-orang Arab maupun non-Arab.

Rujukan utama bahasa Arab khusus gramatikalnya pada masa Abbasiyah adalah orang-orang Badui, karena mereka memandang bahwa hanya orang Baduilah yang memiliki keaslian bahasa itu. Di sisi lain, bahasa kelas menengah ke bawah yang dikenal sebagai bahasa Ammiyah (yang merupakan percampuran antara bahasa Arab dengan bahasa setempat) mulai tumbuh dan lansung marak, dan pada abad ke III pengaruh Ammiyah sangat kuat ${ }^{29}$, sampai ditemukan dalam tulisan-tulisan ilmiyah banyak yang mempergunakan bukan bahasa Arab asli.

\footnotetext{
${ }^{29}$ Pada abad III H pengaruh bahasa Arab 'amiyyah nampak lebih jelas pada kelompok awam, bahkan sudah mulai terdapat buku-buku ilmiyah ditulis dengan bahasa yang kurang murni, karena mengandung gaya bahasa dan kata-kata bahasa Arab Muwalladah. Jadi, pada pertengahan abad III H, bahasa percakapan mengalami kemunduran yang menyedihkan, banyak para pejabat yang berbicara dengan menggunakan bahasa 'amiyyah, akibat unsur non-Arab semakin banyak menduduki jabatan penting dan semakin jauh mencampuri masalah-masalah politik dan pemerintahan. Bahkan para ahli nahwu pun pada akhir abad ini menggunakan bahasa "amiyyah dalam bahasa percakapan mereka sehari-hari. Lihat Latifah salim, "Sejarah Pertumbuhan dan Perkembangan Bahasa Arab", Jurnal Diwan, Vol. 3 Nomor 1/2017, h.
} 
Pada abad ke IV hijriah, orang-orang tidak lagi belajar lansung kepada orangorang Badui, tetapi hanya lewat karangan-karangan Badui yang sudah banyak di pasaran buku-buku. ${ }^{30}$ Bahasa Arab -baca: fusha- di abad ini masih menjadi bahasa administrasi, politik dan lain-lain, namun pada abad ke V, bahasa Arab hanya sebagai bahasa agama saja, sementara karangan para cendekia kadang menggunakan bahasa Persia.

Minat untuk mempelajari bahasa al-Qur'an ini terus terkikis hingga abad ke VI. Kemerosotan ini bersamaan dengan munculnya kaum Saljuk dan berhasilnya bangsa Mongolia menduduki negara-negara Islam.

Setelah bahasa Arab fusha semakin menipis peminatnya, maka muncullah bahasa Ammiyah sebagai penggantinya, namun ini pun tak bisa bertahan dengan arus percampuran bangsa-bangsa asing yang tidak disadari sedikit demi sedikit masuk ke dalam bahasa Ammiyah, dan dipakai dalam masyarakat hingga kini.

\section{Masa Depan Bahasa Arab}

Jika dunia Eropa pada abad pertengahan mengalami kegelapan, sebaliknya pada saat itu ilmu pengetahuan dan filsafat Yunani dapat dipelihara dan dikembangkan oleh umat Islam di Timur, meskipun kemudian, pada zaman kebangkitan dunia Barat ilmu pengetahuan dan filsafat Yunani itu diambil alih dari umat Islam di Asia maupun di sebagian Eropa sendiri. ${ }^{31}$ Sejak saat itu, Eropa-Barat semakin bersinar dengan cahaya ilmu pengetahuan dan teknologi, sementara dunia Islam semakin tertinggal bersamaan dengan melemahnya semangat mengkaji alQuran dan bahasanya hingga dewasa ini.

Mencermati fenomena bahasa Arab yang cenderung mengalami stagnasi perkembangan, muncul keprihatinan bahwa bahasa Arab di Timur Tengah, tempat asal dan lahirnya bahasa Arab tersebut, sudah mulai kurang diminati. Bahkan ada yang berpendapat, bahasa di Timur Tengah sudah menuju kepunahannya. ${ }^{32}$

Kemerosotan bahasa Arab dalam medan kehidupan secara global, menurut Muhammad Galib Abd Rahman Warraq, disebabkan oleh fitnah dan stigmatisasi buruk terhadap bahasa Arab. Di antara stigma buruk yang paling menonjol sebabagai berikut:

1. Bahasa Arab itu sulit gramatikanya, pengajarannya, banyak penyimpangan (dari kaidah),

2. Bahasa Arab sulit ditulis dan diekspresikan dengan fusha, karena bahasa Arab (fusha) itu kuno atau ketinggalan jaman, berbeda dengan bahasa 'Ammiyah yang dianggap lebih mengikuti perkembangan zaman,

3. Bahasa Arab itu terbatas kemampuannya dalam penguasaan ilmu-ilmu modern yang menyebabkan dunia Arab mengalami ketertinggalan oleh kemajuan ilmu dan teknologi.

${ }^{30}$ Lihat Mulyanto Sumardi et.el, Pedoman Pengajaran... h. 34-48.

${ }^{31}$ Latifah Salim, "Peranan Bahasa Arab terhadap Ilmu Pengetahuan", Jurnal Adabiyah Vol. 15 Nomor 2/2015, h. 172.

${ }^{32}$ http://afikrizain.blogspot.co.id/2012/07/masa-depan-bahasa-arab.html (diakses tanggal 9 Januari 2018) 
4. Penulisan huruf-huruf Arab sulit dipahami dan dipelajari karena cirinya yang berkelok-kelok dan rumit, karenanya harus diganti dengan abjad atau huruf yang lebih mudah dpelajari dan lebih cepat dipahami. ${ }^{33}$

Selain stigma buruk yang dijadikan fitnah terhadap bahasa Arab, terdapat tantangan lain yang ikut menghalangi langkah maju bahasa Arab pada masa depannya. Warraq menyimpulkan ada empat hal:

1. Persaingan antara bahasa fushah dengan bahasa 'ammiyah

2. Pergulatan dengan bahasa luar

3. Penyebaran bahasa Arab, dan

4. Terminologi bahasa ${ }^{34}$

Keterangan Warraq di atas, senada dengan kesimpulan Muhbib Abd Wahab, bahwa bahasa Arab dihadapkan pada tantangan serius;

Pertama, pelemahan minat, motivasi, dan spirit mempelajari bahasa Arab melalui stigmatisasi bahasa Arab sebagai bahasa yang sukar dipelajari dan dimengerti. Citra negatif seperti itu menurut Fathi Ali Yunus di Mesir pada dekase 1980-an, antara lain, disebabkan oleh kolonialisasi Barat terhadap dunia Islam dengan agenda menjauhkan umat Islam dari bahasa al-Qur'an. ${ }^{35}$ Akibatnya, ebuah penelitian di Malaysia mengenai kesulitan belajar bahasa Arab di perguruan tinggi tahun 2005 menunjukkan bahwa penyebab kesulitan belajar bahasa Arab ternyata tidak disebabkan oleh substansi atau materi bahasa Arab, melainkan pada ketiadaan minat (100\%), tidak memiliki latar belakang bahasa Arab (87\%), materi/kurikulum perguruan tinggi (83\%), kesulitan memahami materi bahasa Arab (57\%), dan lingkungan kelas yang tidak kondusif (50\%). Lebih dari itu, ditemukan bahwa 80\% penyebab kesulitan belajar bahasa Arab adalah faktor psikologis, dan $77 \%$ di antara mereka memiliki kesan negatif terhadap bahasa Arab.

Kedua, karena alasan pragmatisme dan deormaslisme, penggunaan bahasa Arab fusha (standar atau formal) di kalangan masyarakat Arab sendiri juga mulai berkurang frekuensi dan proporsinya. Dalam interaksi sosial kemasyarakatan, bahasa Arab cenderung digantikan dengan bahasa 'Ammiyah (bahasa pasaran) atau dialeg lokal (Saudi, Mesir, Suria, Sudan, dan sebagainya). ${ }^{36}$

Fenomena melemahnya pemertahanan bahasa dengan kendornya minat mempelajari dan menggunakan bahasa Arab apalagi sastra Arab membawa kepada kemunduran bahasa Arab hingga pada titik mengkhawatirkan. Salah satu fenomena kemunduran yang digambarkan Muhammad Al-Gazali adalah dengan serta merta menerima bahasa masukan atau pengaruh bahasa Asing yang merusak bahasa fusha. ${ }^{37}$

\footnotetext{
${ }^{33}$ Lihat Muhammad Galib Abd Rahman Warraq, Șafahāt min al-Lugah wa al-naḥw (Khurtum: Syirkah Matabih al-Sudan li al-Umlah al-mahdudah, 2015), h. 6-7.

${ }^{34}$ Lihat keterangan lebih lanjut Muhammad Galib Abd Rahman Warraq, Șafahăt min al-Lugah wa al-nahw, h. 9-31.

${ }^{35}$ http://repository.uinjkt.ac.id/dspace/bitstream/123456789/28591/3/MUHBIB\%20ABDUL \%20WAHAB-FITK.pdf (diakses tanggal 10 Januari 2018)

${ }^{36}$ Muhbib abdul Wahab, Masa Depan Bahasa Arab di Indonesia,

${ }^{37}$ Muhammad al-Gazali, Syariat dan Akal dalam Perspektif Tradisi Pemikiran Islam h. 222.
} 
Seiring dengan perkembangan ilmu pengetahuan dalam abad ke-20 ini, bahasa telah berkembang sebagai bahasa untuk menguraikan berbagai cabang ilmu pengetahuan baik secara lisan maupun tulisan. Bahasa pengantar perkuliahan dalam fakultas seperti fakultas ekonomi, sosial politik, teknik dan kedokteran dan berbagai universitas di Negara-negara Arab adalah bahasa Arab. Begitu pula buku-buku yang digunakan kebanyakan dalam bahasa Arab. ${ }^{38}$ Hanya saja pada berbagai bidang tersebut terdapat kosa kata serapan yang dengan serta merta diadopsi bahasa Arab tanpa adanya upaya pemertahanan, seperti dalam bidang penyiaran, astudiyu (studio), tist (test), satanbai (stand by). Dalam bidang oleh raga, muncul kata al-jul (gol), alkurnar (corner), dalam perdagangan muncul kata butik (butik), subar marikat (supermarket). Adapun dalam bidang perhotelan, apotik, dan rumah sakit, bahasa Arab masih dianggap rendah. Termasuk musibah dengan munculnya keputusan untuk menyingkirkan bahasa Arab dari dunia kedokteran, teknik, dan segala institusiinstitusi ilmiah. Kosa kata peradaban modern setiap hari membawa kata-kata asing yang memengaruhi bahasa Arab, yang aneh, justru ulama-ulama al-Azhar terpengaruh dengan majistir (magister), dukturah (doktor) ${ }^{39}$

Pengaruh Asing yang tidak sedikit, khususnya dalam kosa kata modern dalam bahasa Arab merupakan dampak lain dari proses mendunianya bahasa ini. Orang Eropa dan Amerika Serikat sudah lama mempelajari bahasa Arab, baik dalam rangka spesialisasi ilmu maupun untuk kepentingan hubungan antarnegara (internasional), atau kepentingan lainnya, bahkan dalam beberapa dekade terakhir ini bahasa Arab memeroleh perhatian khusus dari seluruh negara non-Arab di dunia, hinggan bahasa Arab menjadi salah satu bahasa resmi yang digunakan dalam forum internasional semisal Perserikatan Bangsa-Bangsa. ${ }^{40}$

Muhammad Al-Gazali memberikan solusi pemertahanan bahasa Arab di masa depan bahwa orang Arab semestinya tekun dalam mengajarkan bahasa dan sastra Arab. Mereka harus menggali banyak khazanah dari tradisi intelektual Islam. Demikian juga muslim yang non-Arab dapat mendalami bahasa wahyu ini dan mendekatkan diri kepada Allah swt dengan meningkatkan perangkaian kata Arab dalam bentuk tulisan dan lisan. ${ }^{41}$

Adapun sekaitan dengan fenomona lemahnya pemertahanan bahasa Arab fusha, Ahmad Musa Salim pernah berkata bahwa turunnya al-Qur'an menjadikan bahasa Arab bernilai tinggi dan memperjelas risalahnya. ${ }^{42}$ Ungkapan ini cukup menjadi peringatan dan pelajaran untuk generasi muslim agar senantiasa memelihara al-Qur'an dengan senantiasa membaca, mengkaji, dan menulis serta menyebarluaskan hasil

${ }^{38}$ Latifah Salim, "Peranan Bahasa Arab terhadap Ilmu Pengetahuan”, Jurnal Adabiyah Vol. 15 Nomor 2/2015, h. 174.

${ }^{39}$ Muhammad al-Gazali, Syariat dan Akal dalam Perspektif Tradisi Pemikiran Islam, h. 222.

${ }^{40}$ Lihat Acep Hermawan, Metodologi Pembelajaran Bahasa Arab (Cet. I; Bandung: PT Rosda Kaya, 2011), h. 26.

\footnotetext{
${ }^{41}$ Muhammad al-Gazali, Syariat dan Akal dalam Perspektif Tradisi Pemikiran Islam, h. 226.

${ }^{42}$ Muhammad al-Gazali, Syariat dan Akal dalam Perspektif Tradisi Pemikiran Islam, h. 231.
} 
kajian kitab suci itu dengan bahasa al-Qur' an itu sendiri.

Masa depan bahasa Arab, seperti juga bahasa-bahasa lainnya ditentukan beberapa faktor, di antaranya faktor sosial, kebudayaan, agama, dan politik. ${ }^{43}$ Masyarakat penutur bahasa Arab sudah sepantasnya menyadari faktor-faktor tersebut dan memanfaatkan segala potensi terutama perkembangan teknologi dan informasi untuk lebih memasyarakatkan bahasa Arab dalam berbagai kepentingan.

\section{Kesimpulan}

Bahasa Arab berkembang secara pesat seiring demgan laju perkembangan umat Islam, dan sebaliknya bahasa Arab mengalami stagnasi seiring dengan kemunduran umat Islam. Kelambanan bahasa Arab yang cenderung menunjukkan stagnanasi bahkan mundur disebabkan karena anyak factor. Di antara faktor iutu ada dua factor dominan, yaitu muncul stereotip dan stigama buruk terhadap bahasa Arab, juga karena mengahadapi banyak tantangan. Masa depan bahasa Arab ditentukan dengan kemampuan penuturnya, terutama girah umat Islam untuk memanfaatkan dan mengembangkan bahasa Arab, di samping bahasa Arab harus mampu menghadapi dan mengatasi berbagai tantangan.

\section{Daftar Pustaka}

Ali, K. "A Study of Islamic History", diterjemahkan oleh Ghufran A. Mas'adi dengan judul Sejarah Islam dari Awal Hingga Runtuhnya Dinasti Usmani, Tarikh Pra Moderen, ed. I. Cet. I; Jakarta: Raja Grafindo Persada, 1997.

Arsyad, Azhar. Bahasa Arab dan Metode Pengajarannya, Beberapa Pokok Pikiran. Fak. Tarbiyah IAIN Alauddin Ujung Pandang, 1997

Broklaman, Karl. Tarikh al-Adab al-Arabiy, jilid I. Cet. IV; al-Qahirah Dar alMa'arif, t.th.

Cahyono, Bambang Yudi. Kristal-Kristal Ilmu Bahasa. Cet. I; Surabaya: Airlangga University Press, 1995.

Al-Faraj, Muhammad Ahmad Abu. Muqaddimah Li Dirasah Fiqh al-Lughah. Beirut: Dar al-Nahdah al-Arabiyah, t.th.

Al-Gazali, Muhammad. Turāsunā al-fikra fí mizān al-syari ‘ wa al- 'aqli diterjemahkan Halid al-Kaf dan Muljono Domopolii dengan judul Syariat dan Akal dalam Perspektif Tradisi Pemikiran Islam. Cet. I; Jakarta: Lentera, 2001.

Al-Ghulâyainiy, Al-Syaikh Mushtafa. Jami' aj-Durâs al-A rabiyah, jilid 1. Beirut; alMaktabah al-Ashniyah, 1973.

Haniah. Bahasa Dasar: Bahasa Arab Komunikasi. Cet. I; Gowa: Pustaka Al-Maidah, 2017.

Hermawan, Acep. Metodologi Pembelajaran Bahasa Arab. Cet. I; Bandung: PT Rosda Kaya, 2011.

\footnotetext{
${ }^{43}$ Lihat Acep Hermawan, Metodologi Pembelajaran Bahasa Arab, h. 24-27.
} 
Hitti, Philip K. "The Arab Short History", diterjemahkan oleh Ushuluddin Hutagalung dan O.D.P. Sihombing dengan judul Dunia Arab (Cet. III; Bandung: Sumur Bndung, t.th), h. 7.

http://afikrizain.blogspot.co.id/2012/07/masa-depan-bahasa-arab.html (diakses tanggal 9 Januari 2018)

http://repository.uinjkt.ac.id/dspace/bitstream/123456789/28591/3/MUHBIB\%20AB DUL\%20WAHAB-FITK.pdf (diakses tanggal 10 Januari 2018)

Al-Naqah, Mahmud Kamil. Ta'lim al-Lugah al' Arabiyah li al-natioqin bi Lugat Ukhra Ushuluhu Mudaakhiluhu, Turuqu Tadrisihi. Makkah al-Mukarramah: Jami'ah Umm al-Qura, 1985.

Al-Qattan, Manna'. Mabahis Fi 'Ulum al-Qur'an. Cet. II; t.tp, Masyurat al-Asr alHadis, t.th.

Al-Rasikh, Abd al-Mannan. Mu'jam Istilāhāt al-Hadis al-Nabawiyy diterj. oleh Asmuni, Kamus Istilah-istilah Hadis. Cet. I; Jakarta: PT Darul Falah, 2006.

Salim, Latifah. "Peranan Bahasa Arab terhadap Ilmu Pengetahuan", Jurnal Adabiyah Vol. 15 Nomor 2/2015. Diakses pada http://journal.uinalauddin.ac.id/index.php/adabiyah/article/view/701/pdf 50

Salim, Latifah. "Sejarah Pertumbuhan dan Perkembangan Bahasa Arab", Jurnal Diwan Vol. 3 Nomor 1/2017. Diakses pada http://journal.uinalauddin.ac.id/index.php/diwan/article/view/2928/pdf

Shalih, Shubhi. Dirasat fi Fiqhi al-Arabiyah. Cet. II; Beirut: Mansyurat al-Maktabah al-Ahalliyah, $1962 \mathrm{M} / 1382 \mathrm{H}$.

Subhi, Ali Ali. "Nazhariyyah al-Jalal: Mukjizat Bahasa al-Qur'an Sepanjang Masa" dalam wawancara oleh PSQ, Jurnal Studi al-Qur'an, Vol II, No 2, Tahun 2007, h. 485.

Suhaib, Muhammad Suyuti. Kajian Puisi Arab Pra Islam. Cet. I; Jakarta: Al-Qushwa, 1990.

Sumardi, Mulyanto, et.el, Pedoman Pengajaran Bahasa Arab Pada Perguruan Tinggi Agama Islam IAIN. Jakarta: Proyek Pengembangan Sistem Pendidikan Agama, Departemen Agama RI, 1975.

Tawwab, Ramadan Abdul. Fusul fi Fiqh al-Lughah. Cet. II; al-Qahirah: Maktabah alHaniji, 1980.

Umam, Chatibul Aspek-aspek Fundamental Dalam Bahasa Arab. Cet. 1; Bandung: PT al-Ma'arif, 1980.

Umam, Chatibul, et.el. Pedoman Pengajaran Bahasa Arab Pada Perguruan Tinggi Agama IAIN. Jakarta Proyek Pengembangan Sistem Pendidikan Agama RI, 1975.

Wafiy, Ali Abd. Wahid. Ilmu al-Lugah. Cet. V; Mișra: Lajnah al-Bayān al-'Arabiy, 1962.

Al-Zubaidy, Ahmad Husen. tärikh al-Adab al-Arabì, Cet. XXV, t, tp. 